\title{
COVİD-19 SALGIN DÖNEMİNDE MUHASEBE VE FİNANS GRUBU DERSLERİ VEREN AKADEMİSYENLERİN UZAKTAN EĞİTİMDE YAŞADIĞI SORUNLARIN İNCELENMESİ: BEU ÖRNEĞİ
}

EXAMINATION OF THE PROBLEMS EXPERIENCED BY ACADEMICIANS WHO TEACH ACCOUNTING AND FINANCE GROUP COURSES IN DISTANCE EDUCATION DURING THE COVID-19 EPIDEMIC PERIOD: BEU EXAMPLE

\author{
Nazan GÜNGÖR KARYAĞDI \\ Öğretim Görevlisi, Bitlis Eren Üniversitesi, \\ Sosyal Bilimler Meslek Yüksekokulu, \\ Muhasebe ve Vergi Uygulamaları, \\ Bitlis/Türkiye. \\ Lecturer, Bitlis Eren University, \\ Social Sciences Vocational School, Accounting and Taxation, \\ Bitlis /Turkey. \\ ngkaryagdi@beu.edu.tr \\ ORCID ID: 0000-0003-3938-4147 \\ Makale bilgisi | Article Information \\ DOI: $10.47994 /$ usbad. 832597 \\ Makale Türü / Article Type: Araştırma Makalesi / Research Article \\ Geliş Tarihi / Date Received: 27.11.2020 \\ Kabul Tarihi / Date Accepted: 27.12.2020 \\ Yayın Tarihi / Date Published: 20.12.2020 \\ Yayın Sezonu / Pub Date Season: Aralık / December
}

Bu Makaleye Atıf İçin / To Cite This Article: Güngör Karyağdı, N. (2020). Covid-19 Salgın Döneminde Muhasebe ve Finans Grubu Dersleri Veren Akademisyenlerin Uzaktan Eğitimde Yaşadığı Sorunların İncelenmesi: BEU Örneği. USBAD Uluslararası Sosyal

Bilimler Akademi Dergisi 2(4), 1253-1275.

Intihal: Bu makale intihal.net yazılımınca taranmıştır. İntihal tespit edilmemiştir.

Plagiarism: This article has been scanned by intihal.net. No plagiarism detected.

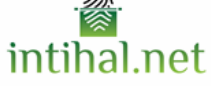

İletişim: Web: https://dergipark.org.tr/tr/pub/usbad mail: usbaddergi@gmail.com 


\section{Nazan Güngör Karyağdı}

Öz: Bu çalışmada, pandemi döneminde muhasebe ve finans grubu dersleri veren akademisyenlerin uzaktan eğitimde yaşadıkları sorunların incelenmesi hedeflenmektedir. Bu amaç çerçevesinde Bitlis Eren Üniversitesinde muhasebe ve finans alanlarında ders veren öğretim üyelerinin/ öğretim elamanlarının bu konuda yaşadıkları sorunları tespit etmek amacıyla, 11 akademisyenle görüşme formu tekniği kullanılarak yarı yapılandırılmış görüşme gerçekleştirilmiştir. Elde edilen sonuçlar ise betimsel olarak analiz edilmiştir. Çalışmadan elde edilen verilere göre; uzaktan eğitim yüz yüze eğitimin gölgesinde kalmış; yüz yüze eğitimin akademisyenler tarafından verimli ve etkin bir eğitim yöntemi olduğu sonucu elde edilmiştir.

Anahtar Kelimeler: Muhasebe, Finans, Pandemi, Akademisyen

Abstract: In this study, it is aimed to examine the problems experienced by academicians who taught accounting and finance group courses in distance education during the Covid-19 epidemic period. For this purpose, a semi-structured interview was conducted with 11 academics using the interview form technique in order to determine the problems experienced by faculty members who teach in the fields of accounting and finance at Bitlis Eren University. The results were analysed in descriptive terms. According to the data obtained from the study, distance education could not be a perfect substitute for face-to-face education and the result is that face-toface education is a more efficient and effective method of education for academics.

Keywords: Accounting, Finance, Pandemic, Academician

\section{GİRIŞ}

Covid-19, tüm dünyayı kısa sürede etkisi altına alan ve ilk etkileri Çin'in Wuhan kentinde ortaya çıkan bulaşıcı bir hastalık olarak tanınmıştır. Halk sağlığını olumsuz yönde etkileyen bu hastalık toplumu ciddi boyutlarda tehdit eden bir hastalıktır. Çin'de ortaya çıkıp ilerleyen zamanla diğer ülkeleri de etkisi altına alan bu hastalık, insanların hayatını her yönüyle kısıtlayan bir hal almıştır. Bu kapsamda virüsün etkisinin görüldüğü tüm dünya ülkelerinde hastalığın topluma yayılmasını engellemek maksadıyla çeşitli önlemler alınmıştır. Sağlık, ekonomi, ulaşım, gıda, kültür, turizm, eğitim vb. gibi konularda ülke hükümetlerince bir dizi önlemler alınarak salgının tehlikesinin minimum seviyeye indirilmesi ya da ortadan kaldırılması hedeflenmiştir.

Dünya Sağlık Örgütü tarafından Ocak 2020'de bulaşıcı hastalık konumunda olan Covid-19, "küresel acil durum" olarak belirtilmiştir. Türkiye'de ise ilk olarak kendini 11 Mart 2020 tarihinde hissettiren bu 


\section{Nazan Güngör Karyağdı}

salgın birçok kişinin ölümüne sebebiyet vermiştir. Ülkemiz tarafından da bu salgına karşı çeşitli önlemler alınmıştır. Sağlık alanındaki faaliyetlerin daha da geliştirilmesi, bireylerin gerek ülke içi gerekse ülke dışı seyahatlerinin belirli süreler içerisinde sınırlandırılması, tüm ülkelerden ülkemize olan turist akımının sınırlandırılması, hastalığa yakalanmış bireyler ya da şüpheli olanların karantinaya alınıp yayılma hızını engellemek için karantina önlemleri, eğitim-öğretim faaliyetlerine geçici süreyle ara verilmesi, toplu etkinliklerin (toplantı, düğün, nişan, kongre, miting vb.) geçici süreyle durdurulması, sokağa çıkma sınırlamaları, maske kullanım zorunluluğu ve sosyal mesafe kurallarının uygulanması gibi bir çok tedbir devletin ilgili kurumlarınca alınan önlemler arasında yer almaktadır.

Salgınla pozitif yönde mücadele edebilmek amacıyla topluma hizmet eden ilgili kurumlar hızlıca çalışmaya başlamıştır. Bu kurumlardan biri ülkemizde yükseköğretim noktasında aktif şekilde çalışan Yüksek Öğretim Kurumu (YÖK) olmuştur. Zira, YÖK'e bağlı olan eğitim-öğretim faaliyetlerini gerçekleştiren üniversiteler virüsün yayılmasına sebep olacak en etkili ortamlardan biri olarak görülmektedir. Bunun nedenleri içerisinde; üniversitelere ülkemizin her şehrinden taşınan öğrenci sayısının fazla olması, öğrencilerin virüsün yayıımasını hızlandıracak ortamlara girip çıkmaları (yurt, cafe, toplu taşıma araçları vb.) üniversitelerde çalışan akademik personellerin yurt içi ve yurt dışı akademik faaliyetlere (sempozyum, kongre vb.) katılım oranlarının yüksek olması, erasmus vb. gibi eğitim programları çerçevesinde yurt dışından ülkemize gelen yabancı öğrencilerin bulunması gibi nedenler gösterilebilir. Bunda dolayı, Yüksek Öğretim Kurumu da hızlı bir şekilde insan sağlığını tehdit eden koronavirüs salgınına karşı önlemler alma eğilimi göstermiştir. Bu önemlerin başında bu olumsuz süreç içerisinde üniversiteler de yüz yüze eğitim sisteminden uzaktan eğitim sistemine geçiş gerçeklemiştir. Bu sistem hem dünya çapında hem de ülkemizde uygulanmıştır. Ülkemizdeki üniversiteler hem öğrencilerin hem de akademisyenlerin olumsuz etkilenmemeleri için eğitim-öğretim adına birçok çalışma yaparak en kısa sürede uzaktan eğitim sistemlerini kurup kullanmaya başlamışlardır.

$\mathrm{Bu}$ bilgilere istinaden, bu çalışmada üniversitelerdeki bazı bölüm/programlarda yer alan müfredat derslerinden olan Muhasebe ve Finans grubu dersleri veren akademisyenlerin uzaktan eğitim sistemi ile verdikleri bu derslerde süreç içerisinde karşılaştıkları 


\section{Nazan Güngör Karyağdı}

sorunların tespit edilmesi amaçlanmıştır. Bu amaç doğrultusunda, Bitlis Eren Üniversitesinde çalışan akademisyenlere dönük bir çalışma yapılmış ve çalışmadan elde edilen veriler yorumlanarak çalışama ile alakalı çeşitli değerlendirmelerde bulunulmuştur.

\section{KAVRAMSAL ÇERÇEVE}

Dünya Sağlık Örgütü'ne (WHO) göre; Covid-19, solunum yolu patojeni olan koronavirüs SARS-CoV-2'nin neden olduğu bulaşıcl hastalıktır. DSÖ, bu yeni virüsü ilk olarak 31 Aralık 2019'da Çin Halk Cumhuriyeti'nin Wuhan şehrindeki vakalardan yola çıkarak bu hastalığı tespit etmiştir. Bulaşıcı nitelikte olan bu hastalığın bireylerde göstermiş olduğu çeşitli semptomlar bulunmaktadır. Ateş, kuru öksürük ve yorgunluk görülen en belirgin semptomlar içerisinde yer alır. Daha az yaygın olan ve beraberinde bazı hastalıkları etkileme gücüne sahi olabilecek diğer semptomlar ise, tat ve koku hissinin kaybolması, burunda tıkanıklık oluşması, boğazda ve başta oluşan ağrı, kaslarda ya da eklemlerde meydana gelen ağrılar, ciltte oluşan döküntüler, mide bulantısı ya da kusma, baş dönmesi ya da üşümenin ortaya çıkması, ishal ve gözlerin kırmızı hale gelmesi gibi belirtilerdir (Who, 2020).

Tıp literatüründeki diğer tanımlara bakıldığında, Covid-19 olarak adlandırılan bir diğer adı da koronavirüs olarak geçen bu kavram, bireylerde solunum yolu enfeksiyonlarına sebep olan solunum damlacıkları yoluyla bireyden bireye bulaşma riski büyük olan virüs ailesi olarak tanımlanmaktadır (Çakın ve Külekçi Akyavuz, 2020: 166). Başka bir tanıma göre ise, latince bir kelime kökenine sahip olan ve taç anlamını ifade eden koronavirüs, dünyada yaygın olan ve solunum yolu hastalıklarını meydana getiren virüs olarak tanımlanır. İlk olarak 1930 yıllarında ortaya çıkan ve tavuklarda görülen bu hastalığın elektron mikroskop vasıtasıyla tanımlanması çalışmaları ise 1968 yılında gerçekleşmiştir (Arı ve Hayır Kanat, 2020: 460). Bu hastalığın engellenmesini sağlayan herhangi bir aşı ya da ilaç bulunmamaktadır (Çakın ve Külekçi Akyavuz, 2020: 166).

Hastalık; sağıık, ekonomik ev sosyal hayatı etkileyen birçok açıdan olumsuz sonuçları olduğu kadar eğitim alanında da olumsuz sonuçları ortaya çıkmıştır. United Nations (2020) kaynağına göre, dünya çapında öğrencilerin en az \%91'in okulların belirli süreyle eğitime verdikleri aradan etkilendiği belirlenmiştir. Bu süreçte en etkili yol uzaktan eğitim sistemi olmuştur. Devletler, salgına karşı sağılık 


\section{Nazan Güngör Karyağdı}

alanında aldıkları önlemlerle beraber, eğitimin sürekliliği adına ve öğrencilerin eğitimden eksik kalmaması amacıyla uzaktan eğitim sisteminin aktifleşmesi için kararlar almışlardır (Yamamoto ve Altun, 2020: 26). Bu kapsamda uzaktan eğitim kavramını tanımlamak gerekirse, eğitim sisteminde öğrenen tarafla öğreten tarafın mekan olarak biribirlerinden uzak oldukları eğitim şeklidir. İlk olarak 1920'li yıllarda ortaya çıkan bir kavram olan uzaktan eğitimin literatürde farklı tanımlamaları yer almaktadır.

Wisconsin Üniversitesi Sürekli Eğitim Grubu tarafından yapılan tanımlamaya göre uzaktan eğitim, uzakta bulunan kitlelere erişim sağlayabilmek için geniş teknoloji yelpazesi kullanmakla birlikte öğrencilerin etkileşimini sağlayan ve belirli planlar dâhilinde öğretme/öğrenme deneyimi olan bir kavramdır (Kurnaz ve Serçemeli, 2020: 265). Uzaktan eğitim, hayatlarını birbirinden farklı mekanlarda sürdüren öğretmen ve öğrenciler arasındaki iletişimin aktif bir şekilde sağlanması ve gerek öğretmenlere gerekse öğrencilere birçok değişkenden bağımsız olan işbirliğinin ön planda olduğu bir çalışma ortamının sağlanmasıdır (Çakın ve Külekçi Akyavuz, 2020: 166).

$\mathrm{Bu}$ tanımlamaların dışında Wedemeyer tarafından yapılan uzaktan eğitim tanımı ise, "bağımszı çalışma alanı" olarak tanımlamış; ayrıca uzaktan eğitim sistemiyle hem öğretmenlerin hem de öğrencilerin gereksiz iş yükünden kurtulacağını savunmuştur. Uzaktan eğitimin aynı zamanda bireysel farklılıkları da yok ettiğine inanmaktadır. Holmberg'e göre; kendilerine ait ortamlarda eğitim gören öğrencilerin başarılarının daha iyi düzeydedir. Moore ise, okul dışında gerçekleşen bir eğitimi benimseyerek birebir iletişimin varlığı ile başarının daha da artacağını savunmuştur (Moore ve Anderson, 2003: 29-30). Uzaktan eğitimde eş zamanlı (senkron) ve farklı zamanlı (asenkron) olarak iki şekilde iletişim yöntemi vardır. Eş zamanlı uzak eğitim, dijital ortamlarda gerçekleşen, öğrenci ve öğretim işini üstlenen görevlilerin aynı ortamda bulunması yöntemidir. Farklı zamanlı model ise, kayıt altına alınan derslere ilişkin videoların daha sonra tekrar izlenmesi fırsatını sunan; öğrencilere istedikleri zaman derse ait doküman, video gibi olanakları elde etme imkanı sunan yöntem olarak tanımlanır (Solak vd., 2019: 42). Uzaktan eğitim sistemiyle ilgili YÖK tarafından gerek derslerin işlenmesi gerekse sınavların nasıl yapılacağına ilişkin yönetmelikler yayınlanmıştır. 


\section{Nazan Güngör Karyağdı}

Covid-19 ile uzaktan eğitim yapılan derslerden bazıları da muhasebe ve finans grubu derslerinin eğitimidir.Bu bağlamda muhasebe eğitimi, mesleki olarak tanımlanan bu eğitim işletmeye ait kararlarda yararlı bilgilerin tespiti,derlenip toplanması, gerçekliğinin kanıtlanması,bilgilerin denetlenerek raporlanması gibi önemli konularda öğrencilerin yetiştirilmesidir (Koca vd., 2019: 95-96). Muhasebe eğitimi, öğrencileri bir işe hazırlama, mesleki anlamda kalifiyeli olmalarına olanak sağlama ve işi bir hedef olarak kullanmak suretiyle becerilerini geliştirmek adına yapılan çalışmaları kapsayan süreç olarak kullanılmalıdır (Göktürk vd., 2013: 2).

Finans eğitim ya da finans grubu derslerin eğitimi ise, toplumda finansal okur yazarlık düzeyini arttıran, insalarda finans kültürünün oluşmuna katkı sağlayan, bireyleri ekonomik ve finansal konulara iliş̧in kalıpsal davranışlardan ve önyargılardan uzaklaştırmayı amaçlayan, finansal eğitim ve öğretim işlemlerinin tümü olarak tanımlanır (Karyağdı, 2018: 116). Bu bağlamda, muhasebe ve finans grubu derslerin eğitiminde bilinen geleneksel eğitim sisteminden uzaktan eğitim sistemine geçilmesi bir takım zorulukları beraberinde getirmiştir.Bu zorluklar gerek öğrenciler açısından gerekse dersi veren öğretim çalışanları açısından yadsınamaz bir gerçektir.

\section{LITTERATÜR TARAMASI}

Daha önceki çalışmalar incelendiğinde uzaktan eğitim sisteminin birçok konusu açısından ele alındığını görmekteyiz. Eğitime olan yansımaları açısından literatür incelemesi yapıldığında da hem bütünsel olarak hem de spesifik olarak yansıması olduğu görülmektedir. Bu kapsamda uzaktan eğitim ve eğitime olan etkileri üzerine yapılan bir dizi literatür çalışmasına aşağıda yer verilmiştir.

Ayyıldız vd. (2006) çalışmalarında, uzaktan eğitim ve elektronik ortamda verilen eğitim modellerinin muhasebe eğitiminde kullanılmasının ve bu kapsamda eğitim veren akademisyenlerin tutum ve davranışlarını ölçmeyi hedeflemişlerdir. Bu çerçevede yapmış oldukları çalışmaya istinaden anket çalışması uygulamışlardır. Yapmış oldukları araştırma sonucunda, akademisyenlerin uzaktan eğitim sistemiyle muhasebe eğitiminin kendilerine heyecan verdiğini, uzaktan eğitim ile gerçekleşen muhasebe eğitimiyle alakalı her türlü faaliyete katkı sağlamaktan, konuya ilişkin yayınları okumaktan zevk aldıklarını tespit etmişlerdir. Bunun aksine muhasebe eğitiminde 


\section{Nazan Güngör Karyağdı}

uzaktan eğitimin geleneksel eğitim kadar etkili olmadığı ve bu yolla edinilen diplomaların saygınlık ifade etmediğini de belirtmişlerdir.

Düzakın ve Yalçınkaya (2008), çalışmalarında web tabanlı uzaktan eğitim sistemini incelemiş ve öğretim elemanlarının bu sisteme yatkın olup olmadıkları konusunda bir araştırma yapmışlardır. Araştırma örneklemlerini Çukurova Üniversitesi bünyesinde çalışan öğretim elemanlarından seçip, bu gurubun araştırma konusundaki yatkınlık durumunu araştırmışlardır. Çalışma verilerinden elde edilen sonuçlarda uzaktan eğitimin etkin kullanılmadığı, çoklu ortam oluşturma ve internet ortamında ders sunumu gibi durumlarda etkin olmadıkları ortaya çıkmıştır.

Gürer vd. (2016), yaptıkları mülakat teknikli çalışmalarında, uzaktan eğitim sistemi ile ilk kez karşı kaşıya kalan öğretim elamanlarının görüşlerini incelemeyi amaçlamışlardır. Çalışmaya istinaden Abant İzzet Baysal Üniversitesinde çalışan ve ön lisans/ lisans düzeylerinde eğitim veren öğretim elemanlarıyla görüşme yaparak bir değerlendirme yapmışlardır. Görüşmeler sonucunda; öğretim elemanlarının uzaktan eğitimin yönetimine yönelik görüşlerine, derslerin içeriklerine yönelik görüşlerine, öğrenmeöğretme süreciyle ilgili görüşlerine yer verilmiştir. Ve araştırmaya konularına yönelik görüşler değerlendirildiğinde öğretim elemanlarının uzaktan eğitim ders verebilecek dirence sahip oldukları, öğrencilerin bu eğitim modelinde pasif kaldıkları ve öğrenci motivasyonlarının olumlu olmadığı gibi değerlendirmeler yapılmıştır.

Kaya vd. (2017), uzaktan eğitim modeliyle ilgili, lisansüstü eğitim veren programlarda ve eğitim bilimleri bölümünde ders veren akademisyenlerin görüşlerini incelemek üzerine bir çalışma yapmışlardır. Ders veren akademisyenlerle görüşme tekniklerinden olan yarı yapılandırılmış görüşmeyle bir çalışma yapıp; çalışma sonucunda geleneksel eğitimin uzaktan eğitimden daha başarılı olduğunu, akademisyenlerin uzaktan eğitime olumsuz bakış açılarının olduğu sonucuna varmışlardır.

Günlük vd. (2019), yaptıkları anket uygulamalı çalışmalarında muhasebe akademisyenlerinin muhasebe eğitiminde uzaktan eğitim yönteminin kabullerini etkileyen faktörlerin Teknoloji Kabul Modeli kapsamında ortaya koymayı amaç edinmişlerdir. Çalışma sonucunda, akademisyenlerin \%38, $5^{\prime}$ inin uzaktan eğitim yöntemiyle ders verdiklerini; \%61, $5^{\prime}$ inin ise gelecekte bu yöntemle ders 
verebileceklerini ifade ettiklerini tespit etmişlerdir. Ayrıca Teknoloji Kabul Modelinin uzaktan eğitim yönteminde muhasebe alanında çalışan akademisyenlerce kullanılabileceğini ve bu yöndeki akademisyen tutumlarının pozitif ve anlamlı istatistiki etkiye sahip olduğu görüşüne varmışlarıdır.

Yıldızhan ve Güçlü (2019), hazırlamış oldukları çalışmalarında eğitim yönetimi alanında tezsiz yüksek lisans programlarında uzaktan eğitim yönteminin kullanılması konusunda akademisyenlerin görüşlerine başvurmuşlardır. Araştırmada yarı yapılandırılmış görüşme tekniği kullanılmış olup; bu eğitim modeliyle ilgili gerekli teknik alt yapı olmaması ve yeterli öğretim üyesi olmaması halinde bu programın açılmasına izin verilmemesi gerektiği yönünde değerlendirmelerde bulunmuşlardır.

Kayaduman ve Demirel (2019) çalışmalarında, uzaktan eğitimi ilk kez kullanan eğitmenlerin bu konudaki düşüncelerini ve tereddütlerini araştırmışlardır. Ve bu bağlamda araştırmaya katılan eğitmenlere uzaktan eğitime yönelik oryantasyon eğitimi vererek, uzaktan eğitim vermelerini sağlamışlardır. Araştırmanın sonunda, eğitmenlere teknoloji, pedagoji vb. konularda çeşitli eğitimler vererek eğitmenler arasında iş birliğinin ön planda olmasının gerekliliğini önermişlerdir.

Kurnaz ve Serçemeli (2020) çalışmalarında, Covid-19 pandemi sürecinde uzaktan eğitim yöntemini kullanarak eğitim veren muhasebe akademisyenlerinin bu eğitim modeline bakış açılarını, bu yöntem çerçevesindeki yeterlilikleri ve muhasebe dersine yönelik görüşlerinin belirlenmesini tespit etmeyi amaçlamışlardır. Bu doğrultuda Türkiye'de faaliyet gösteren devlet ve vakıf üniversitelerini kapsayan bir çalışma yağmış ve anket uygulamasıyla çalışmalarına destek vermişlerdir. Çalışma sonucunda, uzaktan eğitim sisteminin akademisyenlerce benimsendiğini ve sistem kullanımı açısından akademisyenlerin yeterli olduğunu belirlemişlerdir. Eğitim sürecinde eğitmen ve öğrenciler arasından iletişim eksikliği, teori ve pratiğin bir arada uygulanmama gibi sorunların ortaya çıktığı görülmüştür. Ayrıca pandemi sürecinden sonra muhasebe alanındaki derslerin tekrar edilmesi kanısına varılmıştır.

Karakaya (2020), bu çalışmasında lisans eğitiminde yer alan işletme fakülteleri ve diğer fakülte ya da programlarda öğrencilerin gelişimine katkı sağlayacağı düşünülen finansal muhasebe gibi 
derslerin uzaktan eğitim modeliyle verilmesi esnasından ortaya çıkan intibak problemleri ve bunlara ilişkin çözüm önerilere yer vermiştir.

Tanyıldızı ve Semerci (2005), bu çalışmada çevrim içi eğitime yönelik hem öğretime elemanı hem de öğrenci görüşlerinin incelenmesi amaçlanmıştır. Ve bu kapsamda Anadolu Üniversitesi, Fırat Üniversitesi, Orta Doğu Teknik Üniversitesi ve Sakarya Üniversitesinde çalışan öğretim elamanlarına ve öğrencilerine yönelik anket çalışması yapılmıştır. Araştırma sonucunda; öğretim elamanlarına göre çevrim içi eğitimin başarılı olduğu kanısı ortaya çıkmıştır. Ayrıca öğretim elamanları bu eğitim sisteminin geleneksel eğitime destek olabileceği düşüncesi içerisinde olmuşlardır. Ve öğretim elamanlarına göre çevrimiçi eğitim yüz yüze eğitimden daha fazla zaman almaktadır. Öğrenciler ise bu eğitim sisteminin geleneksel eğitim sisteminden daha etkili olmadığını ifade etmişlerdir. Ayrıca hem öğretim elemanları hem de öğrenciler bu sistemde yapılan sınavları kısmen geçerli bulmuşlardır.

Literatür taraması sonucu incelenen çalışmaların uzaktan eğitim sisteminde karşılaşılan sorunları ve bunlara dönük önerileri içerdiğini görmekteyiz. Çalışmalarda uzaktan eğitime hem bütünsel açıdan hem de tek ders bazında bakış açıları değerlendirilmiş olup, araştırma yöntemleri olarak nicel veri analizleri ve nitel veri analizleri kullanılmıştır. Bu çalışmada uzaktan eğitim sisteminde ders veren akademisyenlerin gelişen şartlara bağlı olarak zorunlu bir şekilde bu sisteme geçişin avantaj/dezavantajlarının neler olduğunun ve yaşadıkları sorunların ortaya konulması açısından faydalı olacağı düşünülmektedir.

\section{YÖNTEM}

\subsection{Araştırmanın Yöntemi}

Bu çalışmada nitel veri toplama yönteminden yararlanılmış olup; görüşme tekniği kullanılmıştır. Bu kapsamda nitel araştırma yöntemi, disiplinler arası bütüncül bakış açısını temel alan, araştırmaya konu olan problemleri yorumlayıcı bir şekilde incelemeyi amaçlayan yöntem olarak tanımlanmaktadır. Bu yöntemde, araştırmaya konu olan olaylar incelenerek, çalışmaya katılan bireylerin olaylara yükledikleri anlamlar dikkate alınarak yorumlanır (Altunışık vd., 2010: 302). Çalışmada nitel veri toplama yöntemleri içerisinde yer alan görüşme tekniği kullanılmıştır. Çalışmamızda, Bitlis Eren Üniversitesi bünyesinde yer alan İktisadi ve İdari Bilimler 
Fakültesi ve Meslek Yüksekokullarında Muhasebe ve Finans grubu dersleri veren akademisyenlerle Covid-19 Salgın Döneminde Uzaktan Eğitimde dersleri verirken yaşadıkları sorunların tespit edilmesi amacyla yarı yapılandırılmış görüşme tekniği kullanılmıştır.

Araştırmanın evrenini Bitlis Eren Üniversitesinde yer alan İktisadi ve İdari Bilimler Fakültesi ve Meslek Yüksekokullarında Muhasebe ve Finans grubu dersleri veren akademisyenler oluşturmaktadır. Araştırmada, katıımcıların yanıtlaması için 6 adet soruyu içeren görüşme formu hazırlanmış ve katılımcıların bu soruları yanıtlanması ve varsa konu ile ilgili başka görüşleri varsa beyan etmeleri talep edilmiştir. Böylelikle, görüşme esnasında katılımcıların çalışma konusuna yönelik görüşlerini belirtmelerine olanak sağlanmıştır.

Katılımcı akademisyenlere yöneltilen sorular uzaktan eğitim modelinde muhasebe ve finans grubu dersleri verirken ne gibi sorunlarla karşı karşıya kaldıklarını içeren sorulardır. Çalışmada yer alan veriler betimsel olarak analize tabi tutulmuş olup; çalışma analizinde katılımcıların görüşlerine istinaden doğrudan alıntılara da yer verilmiştir. Bu araştırma, Bitlis Eren Üniversitesi Etik Kurulu'nun 11.11.2020 tarih ve 2020/10-III sayılı kararıyla uygun bulunmuştur (Evrak Tarih ve Sayısı: 17.11.2020 /66073261/050.3/).

\subsection{Araştırmanın Güvenilirliği ve Geçerliliği}

Nitel yöntemlerle hazırlanmış bir araştırmada toplanan verilerin ayrıntılı olarak rapor edilmesi ve çalışma sonuçlarına nasıl ulaşıldığının açıklanması güvenilirlik ve geçerlilik için önemlidir. Nitel bir araştırma yapıldığında, araştırma sürecinde iç geçerliliğe yönelik araştırmacı tarafından tedbirli davranılması gereken bir takım hususlar vardır. Bunlardan bazıları, araştırmaya ilişkin bulguların kendi içerisinde tutarlı ve anlamlı, kavramsal çerçeveye uygunluğunun olması, ortaya çıkan sonuçların anlamlı bir bütün oluşturmasıdır. Bunun yanısıra, araştırma bulgularını teyit etme ve yorumlamak için uygun stratejiler kullanılmalı, bulgular gerçekçi olmalıdır. Bu kapsamda, bu çalışmada araştırma yöntem ve aşamalarının tanımlanması,araştırmaya yönelik verilerin elde edilmesi,verilerin analizi ve yorumlanması gerçekleştirilmeye çalışılmıştır (Gülbahar ve Koşar, 2020: 10071008). Araştırmanın güvenirliliği ve geçerliliğini belirlemek amacıyla, 
- Güvenirlik: Görüş Birliği/(Görüş birliği+Görüş Ayrılığı)x100 formülü kullanılmıştır (Miles ve Huberman, 2015: 72). Ve bu kapsamda şu sonuçlara ulaşılmıştır:

Araştırmada soruların soruların güvenirliği için gerekli hesaplamalar yapılmış ve soruların güvenilirliği \%83,32 olarak hesaplanmıştır. Görüş birliği yüzdesinin 80 'e yakın değerde olması makul görülmekte olduğundan,bu çalışmada yapılan analizlerin tutarlı olduğu ortaya çıkmaktadır.

\subsection{Araştırma Bulgularının Yorumlanması}

Çalışmada yer alan veriler betimsel olarak analize tabi tutulmuş olup; çalışma analizinde katılımcıların görüşlerine istinaden doğrudan alıntılara da yer verilmiştir.Verilerin analizi yapılmadan önce çalışmaya katılan her katılımcıya bir kod verilmiştir.Ve kod tanımlamamızda akademisyenlerimiz " $A$ " olarak kodlanmıştır.Sorular ise alt kategorilere ayrılarak sınıflandırılmıştır.

Çalışmanın bu kısmında araştırmaya ve yapılan görüşmelere ilişkin sorular doğrultusunda edinilen bulgulardan ve bulgulara ilişkin analiz yorumlarından bahsedilecektir.

\section{4. ÜNVANLARINA İLIŞKİN BİLGİLER}

\begin{tabular}{|lcc|}
\hline Öğretim Üyesi & Öğretim Elamanı & Toplam \\
\hline 2 & 9 & 11 \\
\hline
\end{tabular}

Tablo 1: Katılımcıların Ünvanlarına İlişkin Veriler

Çalışmaya katılım gösteren akademisyenlerin 2'si Bitlis Eren Üniversitesi İktisadi ve İdari Bilimler Fakültesinde görev yapan öğretim üyeleri; 9'u ise Meslek Yüksekokullarında görev yapan öğretim elemanlarından oluşmaktadır. 11 akademisyenden çalışmaya ilişkin veri toplanması sağlanmıştır.

\subsection{Muhasebe ve Finans Grubu Derslere Olan Öğrenci İlgisini Uzaktan Eğitim ve Yüz Yüze Eğitim Açısından Kıyaslanmasına İlişkin Görüşler}

Görüşlerine başvurulan akademisyenlerin "Muhasebe ve Finans Grubu Derslere Olan Öğrenci İlgisini Uzaktan Eğitim ve Yüz Yüze Eğitim Açısından Kıyaslanmasına İlişkin Görüşler" olumlu ve olumsuz olarak değerlendirilmiş ve akademisyenler tarafından bu konuya ilişkin görüşler sunulmuştur. 


\begin{tabular}{|l|}
\hline Görüşler \\
\hline Uzaktan eğitim öğrenci ilgisi açısından Yüz Yüze Eğitime göre \\
daha \\
faydalıdır \\
Yüz Yüze Eğitim öğrenci açısından Uzaktan Eğitime göre daha \\
faydalıdır (10)
\end{tabular}

Tablo 2: Muhasebe ve Finans Grubu Derslere Olan Öğrenci İlgisini Uzaktan Eğitim ve Yüz Yüze Eğitim Açısından Kıyaslanmasına İlişkin Görüşler

Görüşme yapılan akademisyenlerin Uzaktan Eğitim Yöntemi ile Yüz Yüze Eğitim Yöntemini öğrenci ilgisi açısından kıyaslamalarına ilişkin görüşlerine bakıldığında katılım gösteren akademisyenlerin çoğunun yüz yüze eğitimi daha verimli bulduğu görülmektedir. Akademisyenler, yüz yüze eğitimi faydalı bulmalarını; yüz yüze eğitimde devam zorunluluğunun olması, yüz yüze eğitimde öğrencilerin derse katılım düzeylerinin daha yüksek olması, yüz yüze eğitimde öğrencilerin bir araya gelerek beraber çalışma fırsatı olması gibi nedenlerle açıklamışlardır.Bu konuda A1;

- "Uzaktan eğitim ile öğrencileri toparlamak ve derse katılımlarını sağlamak açısından sıkıntılar yaşıyorum. Eski öğrencilerimize kıyasla yeni öğrencilerde bu sorun daha da artıyor. Yüz yüze eğitimde yeni ve eski öğrenci ayrımı olmadan öğrencileri toparlamak ve derse ilgi göstermelerini sağlamak zor olmuyor."

- "Uzaktan eğitimde, öğrencinin çok da fazla motive edilemediği görüşündeyim. Her ne kadar kameradan bizi görseler bile, motivasyon sohbetlerinin onlara geçmediği kanaatindeyim. Yüz yüze eğitimde, dersle ilgili yapılan sohbetlerde motivasyonun arttığını gözlemlediğimi söyleyebilirim."

- "Derse ilgi açısından, öğrencilerin birlikte çalışmaları ve bildiklerini birbirlerine aktarmaları, önemlidir. Bu bağlamda bir arada olan öğrenciler, beraber çalışarak ve hep birlikte katkı sağlayarak daha iyi bir öğrenme ortamı oluşturacaklardır. Uzaktan eğitimde bu pek mümkün değildir."

Görüşme yapılan 11 akademisyenden 9'u yüz yüze eğitim yöntemini daha faydalı bulmuş, 2 akademisyen ise öğrenci ilgisinin sistemli çalışan öğrenci açısından fark etmediği yönünde görüş bildirmiştir.Bu yönde görüş veren A4 ise; 


\section{Nazan Güngör Karyağdı}

- "Sistemli çalışan öğrenci için yüz yüze ya da uzaktan eğitim bir farkı olmuyor, ancak sistemli çalışmayan öğrenci her iki eğitimde de ilgisi yetersiz."

Ayrıca görüşmeye katılan 4 akademisyen sınıf ortamında sorucevap yöntemi, muhasebe ve finans derslerinin öğreniminde kolaylaştırıcı etkiye sahip olan monografi çözümleri gibi yöntemlerin kullanılmasının gerek derse olan öğrenci ilgisini arttırmada gerekse öğrenmeyi kolaylaştırmada etkin olduğu yönünde görüş bildirmişlerdir. Bu açıdan katılımcı görüşlerine bakıldığında, yüz yüze eğitimin uzaktan eğitime oranla daha verimli olduğu sonucu ortaya çıkmıştır.

4.2. Öğrencilere Muhasebe ve Finans Grubu Dersleri Anlatırken Uzaktan Eğitim Yöntemi ve Yüz Yüze Eğitim Yönetimi Arasındaki Avantaj/Dezavantajlarına İlişkin Görüşler

\begin{tabular}{|l|}
\hline Avantaj (Uzaktan Eğitim) \\
Dezavantaj (Uzaktan Eğitim) \\
\hline Daha az efor sarf etme (8) \\
Derslerin anlaşılması noktasında öğrenci takibi yapamama \\
sorunu (9) \\
Daha fazla zaman tasarrufu (8) \\
Kimi öğrencilerin dersi takip edememesi (11) \\
Mekan kısıtlaması olmadan her ortamda derse girebilme fırsatı \\
(11) \\
Avantaj (Yüz Yüze Eğitim) \\
Dezavantaj (Yüz Yüze Eğitim) \\
Öğrencilerin ders katılımının daha fazla olması (10) \\
Muhasebe ve finans grubu derslerde \\
Öğrencilerin çabuk sıkılması (10) \\
Sınıf ortamında öğrenci değerlendirilmesinin \\
Daha etkin yapılması (10)
\end{tabular}

Tablo 3: Öğrencilere Muhasebe ve Finans Grubu Dersleri Anlatırken Uzaktan Eğitim Yöntemi ve Yüz Yüze Eğitim Yönetimi Arasındaki Avantaj/Dezavantajlarına İlişkin Görüşler

Tablo 3'te "Öğrencilere Muhasebe ve Finans Grubu Dersleri Anlatırken Uzaktan Eğitim Yöntemi ve Yüz Yüze Eğitim Yönetimi Arasındaki Avantaj/Dezavantajlarına İlişkin Görüşler"e göre, mekân kısıtlaması olmadan her ortamda derse girebilme fırsatını bütün 
akademisyenler uzaktan eğitimde avantaj olarak görürken; bütün akademisyenler kimi öğrencilerin dersi takip edememe durumunu ise uzaktan eğitimde dezavantaj olarak görmüştür. Bunun nedenlerini ise; öğrencilerin bazılarının derse giriş zamanında teknik sorun yaşaması ya da internet, bilgisayar vb. gibi donanım eksikliği yaşadıkları yönünde görüş bildirmişlerdir.

Görüşme yapılan akademisyenlerden sekizi uzaktan eğitimin zaman tasarrufu sağladığını, geri kalan üçünün ise bu yönde bir düşüncesi olmadığı ortaya çıkmıştır. Yine on akademisyen yüz yüze eğitimin öğrencilerin derslere katılım noktasında ve haliyle sınıf içinde değerlendirme noktasında avantajlı olduğunu vurgularken; bir akademisyen bunun öğrencinin dersi verimli çalışmasına bağlı olarak değişebileceği yönünde fikir beyan etmiştir.

Yine 8 katılımcı uzaktan eğitimin daha az eforla yapılabileceğini ve uzaktan eğitim noktasında avantajlı olduğunu ifade ederken; diğer katılımcılar bu yönde bir görüş bildirmemiştir. Ayrıca dokuz akademisyen, muhasebe ve finans grubu derslerden öğrencilerin sınıf ortamında çabuk sıkıldığını vurgulamış, iki akademisyen ise bunun her iki ortamda da öğrenciye ve başarısına bağlı olduğunu beyan etmiştir. Bütün bu bilgiler ışığında uzaktan eğitimin avantaj/dezavantajlarına, yüz yüze eğitimin avantaj/dezavantajlarına yönelik A7'nin görüşleri aşağıdaki gibidir:

- "Uzaktan eğitimin zaman tasarrufu sağlaması, herhangi bir mekanda bulunma serbestliği, daha az yorulma gibi avantajlardan bahsedebiliriz. Kullanılan araçlarda aksaklıkların meydana gelmesi ve bu araçlara her öğrencinin ulaşamaması, öğrencilerin derse katılımın az olması ve dikkatlerini tam olarak derse verememeleri, öğrencilerle etkili iletişim kurulamaması,

- Yüz yüze eğitimin öğrenci ile etkileşim içinde olma, sağlıklı iletişim kurabilme, sınıf ortamında arkadaşları ile yardımlaşma, öğrencinin dikkatinin dağıldığının tespit edilmesi ve önlem alınması, ödevler verilmesi ve birlikte çözülmesi, tahta kullanımı gibi avantajları varken, belirli bir mekanda bulunma zorunluluğu, öğrencilerin sınıf içinde olumsuz iletişim kurabilmeleri gibi dezavantajları vardır." 
4.3. Muhasebe ve Finans Grubu Derslerdeki Öğrenci Başarısını Uzaktan Eğitim ve Yüz Yüze Eğitim Açısından Değerlendirmeye İlişkin Görüşler

Uzaktan Eğitimi Başarılı Bulanlar

Yüz Yüze Eğitimi Başarılı Bulanlar

Her ikisinde de Başarı Aynı (2)

Tablo 4: Muhasebe ve Finans Grubu Derslerdeki Öğrenci Başarısını Uzaktan Eğitim ve Yüz Yüze Eğitim Açısından Değerlendirmeye İlişkin Görüşler

Tablo 4'de yer alan verilere göre, akademisyenlerin dokuz tanesi yüz yüze eğitimi başarılı bulmuş; uzaktan eğitimi başarısız bulmuşlar ve iki akademisyen ise öğrencilerin muhasebe ve finans grubu derslerde başarısız/yetersiz olduğu yönünde görüş bildirmiştir. Yüz yüze eğitimi başarılı bulmalarının sebebini ise; muhasebe ve finans grubu derslerinin zor dersler olduğunu ve bu derslerin ancak yüz yüze eğitimde verimli bir şekilde öğrencilerce benimsenebileceğini savunmuşlardır. Ayrıca beş akademisyen yüz yüze eğitimde eş zamanlı soru çözümlerinin ve tahta kullanımın öğrencilerin başarısını olumlu yönde etkilediğini vurgulamışlardır. Bu görüşü savunan A5'ün ve $A 1$ 'in görüşünü örnek olarak vermek gerekirse;

- "Yüz yüze eğitim de ise; muhasebe ve finans dersleri daha anlaşılabilir, daha verimli anlatıldığı ve anlaşıldığı kanısındayım, öğrenci başarısı yüz yüze eğitimde daha verimli (tartışmasız) olduğu düşüncesindeyim." (A5)

- "Öğrenci başarısını yüz yüze eğitimde daha çok görme fırsatı yakalıyoruz. Çünkü soruları eş zamanlı çözümlerini isteyerek öğrenciyi değerlendirebiliriz. Ödevleri inceleyip soru sorma fırsatımız oluyor. Uzaktan eğitimde bu avantajlar yok denecek kadar az." (A1)

Genel anlamda bütün varsayımlar göz önünde bulunulduğunda katılımcılar tarafından yüz yüze eğitim öğrenci başarısında daha etkili olmaktadır görüşü ortaya çıkmıştır.

4.4. Uzaktan Eğitimde Öğrencilerin Dersi ve Derse Yönelik Verilen Ödevleri Algılama Düzeylerinde Problemler Yaşanmaktadır Düşüncesine İlişkin Görüşler

\begin{tabular}{|ccc|}
\hline Katılıyorum & Katılmıyorum & Toplam \\
\hline 7 & 4 & 11 \\
\hline
\end{tabular}


Tablo 5. Uzaktan Eğitimde Öğrencilerin Dersi ve Derse Yönelik Verilen Ödevleri Algılama Düzeylerinde Problemler Yaşanmaktadır Düşüncesine İlişkin Görüşler

Çalışmaya katılan akademisyenlerin 7'si "Uzaktan Eğitimde Öğrencilerin Dersi ve Derse Yönelik Verilen Ödevleri Algılama Düzeylerinde Problemler Yaşanmaktadır Düşüncesine İlişkin Görüşler" konusunda "Katılıyorum"; 4'ü "Katılmıyorum" yönünde görüş bildirmiştir. Katılımcılara "Katılıyorum" yönünde fikir beyanlarına ilişkin sebepler sorulduğunda öğrencilerin dersi sanal ortamda görmesinden kaynaklı anlama eksikliği oluştuğunu ve derse ilişkin konuları anlayamadıklarından ödevleri de anlama noktasında anlaşılmazlık oluşturduğunu, bazı öğrencilerin evinde uzaktan eğitime dönük gerekli donanımların (internet, bilgisayar vb.) olmadığından derse katılım sağlayamamaları ve bu nedenle ödevleri de başkalarından duyarak anlayamamaları gibi nedenler olduğunu savunmuşlardır. Bu görüşlere katılım sağlayanlara istinaden $A 3$ 'ün ve A8'in görüşleri şöyledir:

- "Üniversitemize gelen öğrencilerin büyük çoğunluğu Doğu Anadolu ve Güneydoğu Anadolu Bölgesi'nden gelmektedirler. Buralardan gelen öğrencilerin ekonomik düzeylerinin düşük olduğu bir gerçek. Bazı öğrencilerimizin evinde internet ve bilgisayar dahi yok. Durum böyle iken bırakın ödevleri algılama düzeylerini, ödevlerini yapabilecekleri bir ortamları var mı acaba?" (A3)

- "Öğrenci uygulama yapamadığından konuları anlayamıyorlar ve sadece sanal olarak görüyorlar. Derse ancak sanal olarak katılıyor, bu bakımdan ödevleri de algılayamıyorlar. Derse bazıları tamamen ilgisiz olup sadece mezuniyet gözüyle bakmaktadır." (A8)

\subsection{Derse katılım Yüz Yüze Eğitimde Daha Disiplinli İken Uzaktan Eğitimde Derse Katılım Disiplini Yeterli Değildir Düşüncesine İlişkin Görüşler}

\begin{tabular}{|ccc|}
\hline Katılıyorum & Katılmıyorum & Toplam \\
\hline 10 & 1 & 11 \\
\hline
\end{tabular}

Tablo 6: Derse katılım Yüz Yüze Eğitimde Daha Disiplinli İken Uzaktan Eğitimde Derse Katılım Disiplini Yeterli Değildir Düşüncesine İlişkin Görüşler 
Tablo 6'da Yüz Yüze Eğitim ve Uzaktan Eğitimin derse katılım noktasındaki disiplin durumu sorulduğunda katılımcıların 10'u Yüz Yüze Eğitimi daha disiplinli bulurken; bir katılımcı bu konuya katılmadığını her iki durumda da öğrenciye bağlı olduğunu vurgulamıştır. Katılım gösterenlere görüşleri sorulduğunda, öğrencilerin muhasebe ve finans grubu derslerden kolay sıkıldıklarını ve eğitmen denetimi olmadığı için de bilgisayar başından kolay uzaklaşabildiklerini, yoklama kaygısı olmadığından derse katılım sağlamadıklarını, videolar kayıt altına alındığından istediğim zaman izlerim mantığı içinde oldukları gibi görüşler bildirmişlerdir. Bu kapsamda A9'a ve A2'e ait görüşler şöyledir:

- "Uzaktan Eğitimde öğrenciyi uzun süre derste tutmak çok zor. Bir bahaneyle dersi dinlemeyenler oluyor. Mesela dersteyim dedikten sonra bilgisayar başında uyuyanlar bile oluyor. Ya da internetim yok dedikten sonra dersten çıkanlar olabiliyor." (A9)

- "İstediğim zaman izlerim mantığıyla canlı katılmıyorlar." (A2)

4.6. Uzaktan Eğitimde İletişim Noktasında Büyük Aksaklıklar Yaşanmaktadır. Bu da Muhasebe ve Finans Grubu Derslerin Anlaşılmasında Zorlukları Beraberinde Getirmektedir Düşüncesine İlişkin Görüşler

\begin{tabular}{|ccc|}
\hline Katılıyorum & Katılmıyorum & Toplam \\
\hline 5 & 6 & 11 \\
\hline
\end{tabular}

Tablo 7: Uzaktan Eğitimde İletişim Noktasında Büyük Aksaklıklar Yaşanmaktadır. Bu da Muhasebe ve Finans Grubu Derslerin Anlaşılmasında Zorlukları Beraberinde Getirmektedir Düşüncesine İlişkin Görüşler

Katılımcılara "Uzaktan Eğitimde İletişim Noktasında Büyük Aksaklıklar Yaşanmaktadır. Bu da Muhasebe ve Finans Grubu Derslerin Anlaşılmasında Zorlukları Beraberinde Getirmektedir Düşüncesine İlişkin Görüşler"e yönelik soru yöneldiğinde $5^{\prime} \mathrm{i}$ "Katılıyorum" 6'sı "Katılmıyorum" yönünde görüş beyan etmiştir. Katılanlara aksaklıkların ne olacağına yönelik soru sorulmuş ve bu kapsamda muhasebe ve finans grubu derslerin anlaşılabilmesi ve soruların karşılıklı tartışıması gibi nedenlerle etkili ve karşılıklı iletişime ihtiyaç olduğunu Uzaktan Eğitimin buna olanak sağlamadığını savunmuşlardır. "Katılmıyorum" yönünde fikir beyan edenlerden 2'si ise dileyen öğrenci dilediği zaman eğitmene erişim sağlayabilir yönünde görüş bildirmiştir. 4'ü ise fikir beyan etmemiştir. 
"Katılıyorum" görüşünü savunanlardan A6'nın ve A7'nin, A10'un görüşü aşağıdadır.

- "Muhasebe dersi uygulamalı ders olduğundan uzaktan eğitimle öğrenileceğini zannetmiyor. Yüz yüze eğitimde defalarca anlatmamıza, öğrencinin tahtada çözmesine ve öğrencinin sürekli soru sormasına rağmen ders ancak anlaşılıyor. Bu ders grubu etkili iletişimi gerektirir. Uzaktan eğitimle öğrencinin öğrenebileceğini zannetmiyorum." (A6)

- "Muhasebe finans grubu derslerinin yeterli etkileşim sağlanamadığı için uzaktan eğitim yöntemiyle tam olarak anlatılabileceğini düşünmüyorum." (A7)

- "Bu dersler öğrenci bakış açısıyla zor olduğundan ve öğrencilerin bol soru çözümüne ihtiyacı olduğundan etkili iletişim şarttır. Sınıf ortamında bile anlamaları ve etkileşim bu kadar zorken uzaktan eğitim de bu durum daha da elzemdir." (A10)

- "Uzaktan Eğitim Sistemine yönelik başka görüşleriniz varsa beyan edebilir misiniz?" yönündeki sorumuza gelen cevaplardan bazıları şöyledir: "Elbette uzaktan eğitim yoluyla muhasebe ve grubu dersler çok rahat bir şekilde verilebilir ve öğrenci tarafından anlaşılabilir. Bununla ilgili çalışmalar mutlaka yapılıyor veya yapılmaktadır. Ancak şu an için öğrencilerimizi bu duruma alışma ve ayak uydurma düzenini sağlamalı, onları eğitime hazır hale getirmek için çalışmalıyız. Öğrenci isteyerek sistemde olmalı, sadece orada ismiyle var olmamalı, etkili bir şekilde derse katılım için sistemsel etkinlikler çoğaltılmalıdır" (A1)

- "Özellikle şunu belirtmek istiyorum. Kişisel görüşüm olarak, hangi üniversite veya eğitim kurumu olursa olsun; uzaktan eğitimin tüm eksiklikleri giderilmiş dahi olsa (alt yapı, üst yapı vs.), yüz yüze eğitim kadar başarılı, sağlıklı ve verimli olamaz. Her şeyden önce "Gözden ırak olan, gönülden de ırak olur." (A3)

\section{SONUÇ}

Bütün ülkeyi olumsuz bir şekilde etkisi altına alan salgın hastalıkların olduğu kriz dönemlerinde uzun vadeli planlamalar yapmak oldukça zordur. Tüm dünyayı etkileyen Covid-19'da buna bir örnek teşkil etmiştir. Yaşanan bu zorlu süreçte eğitimde bu kriz döneminde etkilenmiş ve bu kapsamda üniversiteler de sürece ayak 
uydurmak zorunda kalmışlardır. Diğer ülkelerde olduğu gibi ülkemizde de pandemi süreci nedeniyle yaşanan sıkıntılara istinaden eğitim konusunda büyük öneme sahip olan üniversitelerimizde hızlıca uzaktan eğitim yöntemine geçilmiştir. Gerek akademisyenler gerekse öğrenciler tarafından bu eğitim sisteminde adaptasyon, iletişim, öğrencilerin başarısı, öğrencilerin derse katılımları vb. konularda çeşitli zorluklar gündeme gelmiştir. Bu kapsamda, çalışmada yaşanan süreçte üniversitelerde ilgili bölüm/programlarda okutulan muhasebe ve finans grubu derslerin uzaktan eğitimle verilmesi noktasında yaşanan sıkıntıların akademisyenlerce değerlendirilmesi ve sorunları ortaya çıkarmak hedeflenmiştir. Bu çerçevede çalışmada, katılımcıların ifadeleri doğrultusunda kendilerine ait doğrudan alıntılara da yer verilmiştir. Araştırma neticesinde, muhasebe ve finans grubu veren akademisyenlerin uzaktan eğitimle ilgili görüşlerinin genel olarak olumsuz olduğu, yüz yüze eğitimin uzaktan eğitimden daha verimli sonuçlar doğurduğu tespiti yapılmıştır.

Çalışmada katılımcılar, uzaktan eğitimin daha az eforla yapılması, zaman tasarrufu sağlaması açısından, mekan kısıtlaması olmadan her ortamda derse girme durumunun var olması, yüz yüze eğitim imkanı bulamayan öğrencilere daha kolay erişim sağlanabilmesi gibi avantajları dile getirirken; derslerin anlaşılması noktasında takip yapamama, internet, bilgisayar vb. yoksunluğundan dolayı kimi öğrencilerin dersleri takip edememesi, öğrenme sürecinde karşılaşılan öğrenme güçlüklerinin anında çözülememesi ve bu durumun ardından gelişebilecek sıkıntıların olması, iletişim yöntemlerindeki değişikliğin olumsuz etkileri gibi dezavantajlarından bahsetmişlerdir. Ayrıca yine çalışma verilerine bakıldığında, katıımcıların çoğunun başarı noktasında yüz yüze eğitimi savundukları ortaya çıkmıştır. 2 katılımcı her iki eğitim yönteminde de başarının bu alan derslerinde aynı olduğunu savunmuştur. Yüz yüze eğitimi başarılı bulanlar, uzaktan eğitimde bu alan derslerine yönelik uygulamanın yeterince yapılmadığı, soruların eş zamanlı çözülmesinin başarıyı arttırdığını ve uzaktan eğitimin buna olanak tanımadığını, öğrencilerin bu dersleri kendi becerileriyle başaramadıklarını bu nedenle yüz yüze eğitimin daha başarılı olduğunu savunmuşlardır.

Uzaktan eğitimde verilen ödevlerin algılanmasında zorlukla yaşandığına akademisyenlerin çoğu katılım sağlamıştır. Öğrencilerin dersi uzaktan anlaması zor olduğundan derse yönelik verilen ödevleri de algılamalarının zor olduğunu ifade etmişlerdir. Yüz yüze eğitim 


\section{Nazan Güngör Karyağdı}

sisteminde derse katılım disiplinin uzaktan eğitime oranda çok daha fazla olduğunu savunan akademisyenler bunun nedenini yoklama kaygısının olmaması, uzaktan eğitimde eğitmen denetiminin sınırlı olması ya da hiç olmaması, uzaktan eğitimde öğrenciyi bilgisayar başında derse zorunlu tutmanın zor olduğunu ve öğrencilerin sıkıldığı gibi nedenlere bağlamışlardır. Uzaktan eğitimde iletişimde aksaklıkların yaşanmasına ilişkin katılım gösteren sayısı 5, göstermeyen sayısı ise 6 'dır. Katılım sağlayanlar, muhasebe ve finans grubu derslerin anlaşılmasının zor olmasından dolayı etkili iletişimi gerekli kıldığını ifade ederken; katılmıyorum görüşünü savunanların 2'si öğrencinin iletişim isteğine bağlılı̆ını savunmuş, diğer 4'ü ise fikir beyan etmemiştir.

Bütün bu görüşler ışığında, muhasebe ve finans grubu derslerin hem teori gerektiren hem uygulama gerektiren dersler olduğu için yüz yüze eğitimin daha başarılı olduğu büyük oranda tespit edilmiştir. Özellikle bu derslerin soru çözmeyle daha iyi anlaşılması ve bunun sınıf ortamında daha sağıklı yürütülmesinden dolayı uzaktan eğitimin başarısız olduğu ortaya çıkmıştır. Akademisyenlerin uzaktan eğitime olan bakış açılarının olumsuz olduğu, uzaktan eğitim sürecinde verilen muhasebe ve finans grubu derslerin yüz yüze eğitim sistemine yeniden geçilmesi aşamasında tekrarlanmasının öğrenci açısından olumlu olacağını savunmuşlardır.

Sonuç olarak, hem geleneksel eğitim yöntemlerine ilişkin avantajların hem de uzaktan eğitime ilişkin avantajların birbirini tamamlayarak kullanılması oldukça önemlidir. Bu kapsamda, uzaktan eğitim konusundaki olumsuzlukların giderilmesinde "flipped learning" gibi yöntemler tercih edilirse hem eğitim etkinliği arttırılabilir hem de öğrenci eğitmen arasındaki etkileşim daha da verimli olabilir. Çalışmada, araştırmanın nitel veri toplama yöntemiyle hazırlanmış olması ve sadece muhasebe-finans grubu dersleri veren akademisyenleri kapsaması bir sınırlılıktır. Bu konuya yönelik çalışma yapacak olanlar, daha farklı çalışma gruplarına ulaşabilir ve farklı analizlerle (nicel veri analizi, karma desen, doküman analizi vb.) çalışmalarını destekleyebilirler.

\section{KAYNAKÇA}

Altunışık, R., Coşkun, R., Yıldırım, E. \& Bayraktaroğlu, S. (2010). Sosyal Bilimlerde Araştırma Yöntemleri SPSS Uygulamalı. 6. Baskı. Sakarya: Sakarya Yayıncılık. 
Arı, A. G. \& Hayır Kanat, M. (2020). Covid-19 (Koronavirüs) Üzerine Öğretmen Adaylarının Görüşleri. Van Yüzüncü Yıl Üniversitesi Sosyal Bilimler Enstitüsü Dergisi (Salgın Hastalıklar Özel Sayısı), 459-492.

Ayyıldız, S. Ü., Günlük , M. \& Erbey , S. (2006). Muhasebe Öğretim Elemanlarının Uzaktan Eğitim ve Uzaktan Muhasebe Eğitimine Yönelik Tutumları Üzerine Bir Araştırma. Muhasebe ve Finansman Dergisi 32, 1-14.

Çakın, M. \& Külekçi Akyavuz, E. (2020). Covid-19 Süreci ve Eğitime Yansıması: Öğretmen Görüşlerinin İncelenmesi. International Journal of Social Sciences and Education Research Dergisi 6(2), 166-186.

Düzakın, E. \& Yalçınkaya , S. (2008). Web Tabanlı Uzaktan Eğitim Sistemi ve Çukurova Üniversitesi Öğretim Elemanlarının Yatkınlıkları. Çukurova Üniversitesi Sosyal Bilimler Enstitüsü Dergisi 17(1), 225-244.

Göktürk, İ., Aktaş, M. \& Göktürk, Ü. (2013). Sosyal Bilimler Meslek Yüksekokullarının Eğitim Sürecinde; Uygulama Açısından Karşılaşılan Sorunlar ve Çözüm Önerileri. Electronic Journal of Vocational Colleges (UMYOS Özel Sayı), 1-8.

Gülbahar, Ç. A. \& Koşar, D. (2020). Özel Okul Yöneticilerinin Yetenek Yönetimine İlişkin Görüşlerinin İncelenmesi. Eğitimde Nitel Araştırmalar Dergisi 8(3), 1000-1028.

Günlük, M., Özer, G. \& Özcan , M. (2019). Muhasebe Akademisyenlerinin Muhasebe Eğitiminde Uzaktan Eğitim Uygulamaları Kullanımına Yönelik Algılarının Teknoloji Kabul Modeli Çerçevesinde İncelenmesi. Muhasebe ve Vergi Uygulamaları Dergisi 12(1), 65-90.

Gürer, M. D., Tekinarslan , E. \& Yavuzlap, N. (2016). Çevrimiçi Ders Veren Öğretim Elemanlarının Uzaktan Eğitim Hakkındaki Görüşleri. Turkish Online Journal of Qualitative Inquiry (TOJQI) 7(1), 47-78.

Karakaya, G. (2019). Covid-19 Salgın Sonrası Muhasebe Derslerinin Uzaktan Eğitim Kapsamında Verilmesi Üzerine Değerlendimeler: Finansal Muhasebe Örneği. S. Öz, F. Onursal, \& D. Celayır içinde, Pandemi Sonrası Yeni Dünya Düzeninde Teknoloji Yönetimi ve İnsani Dijitalizasyon (664). İstanbul: Hiperlink Eğitim Yayın. 
Karyağdı, N. G. (2018). Finansal Okuryazarlık ve Farkındalığının Belirlenmesine Yönelik Bitlis Eren Üniversitesi SBMYO Öğrencileri Üzerine Bir Uygulama. İşletme Ekonomi ve Yönetim Araştırmaları 1(2), 110-126.

Kaya, M., Akyol , C., Özbek , R. \& Pepeler , E. (2017). Lisansüstü Eğitim Programlarında" Uzaktan Eğitim Uygulamasına" Yönelik "Eğitim Bilimleri Bölümü" Akademisyenlerinin Görüşleri. Elektronik Sosyal Bilimler Dergisi 16(64), 1616-1627.

Kayaduman, H. \& Demirel , T. (2019). Investigating the Concerns of First-Time Distance Education Instructors. International Review of Research in Open and Distributed Learning 20(5), 85-103.

Koca, N., Güngör Karyağdı, N. \& Akpınar , Y. (2019). Muhasebe ve Vergi Bölümü Öğrencilerinin, Bölüme ve Mesleğe İlişkin Bakış Açıları ve Mesleki Beklentileri Üzerindeki Stajın Etkisi: KSÜ, BEÜ, ADYÜ Örneği. Kahramanmaraş Sütçü İmam Üniversitesi İ.̇.B.F. Dergisi 9(2), 93-110.

Kurnaz, E. \& Serçemeli, M. (2020). Covid-19 Pandemi Döneminde Akademisyenlerin Uzaktan Eğitim ve Uzaktan Muhasebe Eğitimine Yönelik Bakış Açıları Üzerine Bir Araştıma. Uluslararası Sosyal Bilimler Akademisi Dergisi 3(3), 263-288.

M. G. Moore \& Anderson, W. (2003). Handbook of Distance Education . New York : NY Routledge.

Miles, M. \& Huberman, A. (2015). Nitel Veri Analizi: Genişletilmiş Kaynak Kitap. S. Akbaba Altun \& A. Ersoy (Çev. Ed.). Ankara: Pegem Akademi.

Sağlık Bilgileri (Covid-19). (2020). Erişim Adresi: https://www.who.int/emergencies/diseases/novel-coronavirus-

2019/question-and-answers-hub/q-a-detail/q-a-

coronaviruses\#: : text=symptoms Erişim Tarihi:22.10.2020.

Solak, H. İ., Ütebay , G. \& Yalçın , B. (2019). Uzaktan Eğitim Öğrencilerinin Basılı ve Dijital Ortamdaki Sınav Başarılarının Kaşılaştırılması. Açıköğretim Uygulamaları ve Araştırmaları Dergisi 6(1), 41-52.

Tanyıldızı, M. \& Semerci, Ç. (2005). Çevrimiçi Eğitim Uygulamalarına İlişkin Öğretim Elemanı ve Öğrenci Görüşlerinin Belirlenmesi. Türk Eğitim Bilimleri Dergisi 3(2), 197-216. 
Yamamoto, G. T. \& Altun, D. (2020). Coronavirüs ve Çevrimiçi (Online) Eğitimin Önlenemeyen Yükselişi. Üniversite Araştırmaları Dergisi 3(1), 25-34.

Yıldızhan, Y. \& Güçlü, N. (2019). Eğitim Yönetimi Uzaktan Tezsiz Yüksek Lisans Programlarının Öğretim Üyeleri Açısından Değerlendirilmesi. Kuram ve Uygulamada Eğitim Yönetimi Dergisi 25(2), 367-418. 